Stępień K. (2015). Estimated values: the provisions and the write-downs of assets as tools to manipulate financial results of enterprises. Copernican Journal of Finance \& Accounting, 4(1), 157-171. http://dx.doi.org/10.12775/CJFA.2015.011

\author{
KonRad StęPieñ ${ }^{*}$ \\ Cracow University of Economics
}

\title{
ESTIMATED VALUES: \\ THE PROVISIONS AND THE WRITE-DOWNS OF ASSETS AS TOOLS TO MANIPULATE FINANCIAL RESULTS OF ENTERPRISES
}

Keywords: estimated values, provisions, write-downs of assets, financial result.

J E L Classification: M4.

Abstract: The purpose of using estimated values such as: provisions and write-downs of assets is to limit economic risk. Provisions should protect the entity against the adverse effects of future economic events that are possible to predict, and the write-downs of assets should protect the entity against overvaluation of its assets beyond their true value. However, in business practice, these estimates, are often used by the boards of companies to manipulate financial results, both as a tool to increase, as well as to decrease the result.

The purpose of this study is to point out the problem of manipulating financial results of companies through the use of estimated values in the form of provisions and write-downs of assets. It seems that it should be taken seriously, and considered as one of the key problems of the theory, and in particular the practice of accounting.

The following research methods have been used: an analysis of the literature, an analysis of normative acts, deduction method and comparison method.

Translated by Konrad Stępień

Date of submission: April 7, 2015; date of acceptance: May 10, 2015.

* Contact information: stepienk@uek.krakow.pl, Financial Accounting Department, Cracow University of Economics, Rakowicka 27, 31-510 Cracow, Poland, phone: +48122937416. 


\section{INTRODUCTION}

Accounting plays an important role in economic activity, therefore the information produced by this information system, especially its final product - a financial statement, must be reliable and credible and thus useful. Thanks to the information provided by accounting in the form of financial statements a variety of economic decisions are made by numerous users of these statements. Through the spectrum of financial statements of enterprises are evaluated, differentiated and positioned by society. For this reason, a wide range of users of accounting expects that accounting will present a true picture of the financial position of a company and make a reliable measurement of the financial result.

Contrary to the expectations of its users accounting, especially financial reporting, does not always provide strictly consistent with the current state information, on the condition of assets and capital and the results of economic activities of an enterprise. The reason for this, is the use of estimates in the form of provisions and write-downs of assets of a company.

In order to minimize economic risk, accounting permits the taking of preemptive actions. These actions are based on estimated values, which can vary from actual values, however they are intended to protect an entity against any loss, negative effects of other foreseeable economic events or over estimating the value of assets. Among these protective measures, which are based on estimated values, it is worth to mention the creation of provisions and impairment losses of a company's assets (Micherda 2006, 113).

The use of estimated values ought to protect a business entity against economic risks, however, in practice, estimated values are often used to manipulate financial results of companies. Managers of companies use provisions or write-downs of assets to create virtual profits or to reduce high losses, depending on the circumstances. For this reason, the recipients of financial statements should be aware of this problem and explore reporting information on estimated values used in subsequent reporting periods.

The purpose of this study is to point out the problem of manipulating financial results of companies through the use of estimated values in the form of provisions and write-downs of assets. It seems that it should be taken seriously, and considered as one of the key problems of the theory, and in particular the practice of accounting. 


\section{THE RESEARCH METHODOLOGY}

The following research methods have been used: an analysis of the literature, an analysis of normative acts, deduction method and comparison method.

\section{PREMISES TO CREATE PROVISIONS}

Provisions are an economic category of very many controversies related to both the method of their classification in the balance sheet, as well as the method of their valuation. Provisions in the balance sheets are displayed as one of the liabilities. They are a way to finance the assets of a company. However, this is a specific type of financing that can theoretically be treated both as its own source of funding - an element of equity, as well as an outside source of financing - an element of foreign capital (Stępień 2011, 370).

Provisions are a source of financing of company's assets, contributing at the moment of their creation to costs and hence lower profits of a company and so provisions can be treated as part of equity. If the provisions are not used, they are dissolved, which usually results in an increase in revenues and thus an increase in the financial result (Stępień 2013a, 72).

According to M. Gmytrasiewicz i A. Karmańska (2006, 380-381), provisions „represent the equivalent of assets accumulated during a given period to cover expected losses, costs, liabilities, etc. cut backs of assets. Estimating the expected, but uninfluenced by the company, loss of assets, guarantees the company will keep its equity, reproducing - from period to period - its net assets. This directly protects the rights and interests of the owners of capital, making it easier for managers to facilitate the going concern principle".

It is worth noting that, without the creation of provisions an increase in profits in a given reporting period could occur, which in turn could lead to an "exit" of a part of the assets (cash assets) from the company, in the form of paid out dividends or other types of disposal of earned equity surplus.

On the other hand, the recognition of provisions as a component of foreign capital (liabilities) is supported by the fact that, provisions are established for future certain or highly probable liabilities of a company. In the event of the occurrence of circumstances for which the provisions were created, the provisions are dissolved, resulting in an increase in liabilities of a company (sometimes followed by expenditure). Thus, at the time when the company is highly 
probable to have liabilities provisions are created, which are dissolved when a probable liability becomes a real liability (Stępień 2011, 370-371).

In contrast, M. Wojas stresses that "provisions for liabilities, despite the fact that they are classified as foreign capital, will not become a real liability, as long they are a similar source of financing assets as the net profit, with the difference that the net profit may be in the future be withheld by the entity or (and) allocated for the purposes of consumption, and the provisions must in the future be used in accordance with its intended purpose or dissolved for the benefit of the financial result" (Wojas 2008, 205).

In view of the above, it is worth noting that both the Polish Accounting Act and International Accounting Standards (IAS), treat provisions as liabilities. In accordance with Art. 3. 1 Section 21 of the Accounting Act and IAS $37 \S 10$ provisions are liabilities whose maturity or amount are not certain (Fil, Michalczyk 2007, 117).

Due to the fact that, the category of provisions are precarious, there are often doubts as to the necessity of their creation. Therefore, it is worth to note the circumstances and conditions for the creation of provisions laid down by law. Pursuant to Art. 35d of the Polish Accounting Act, provisions are created for:

1) certain or highly probable future liabilities that can be reliably estimated, especially for losses on business transactions, including those due to issued guarantees, warranties, credit operations, effects of pending litigation,

2) future liabilities resulting from restructuring, if under separate regulations the company is obliged to carry it out or if binding agreement have been made in reference to this issue, and if restructuring plans allow to reliably estimate the value of future liabilities.

On the other hand, according to IAS 37 provisions must created when the following three conditions are met:

1) an entity has a present legal or constructive obligation as a result of a past event,

2) it is probable that, the fulfillment of an obligation will result in an outflow of resources which embody economic benefits,

3 ) it is possible make a reliable estimate of the amount of this obligation.

If these conditions are not met, provisions should not be created.

The balance of provisions should be reviewed at each balance sheet date and adjusted to reflect the best, present estimate. Provisions should be used for their original purpose. If the outflow of resources required to settle an ob- 
ligation, for which a provision was created, ceased to be probable, a provision must be dissolved.

Provisions for liabilities are classified as other operating expenses, financial expenses or extraordinary losses, depending on the circumstances of future obligations. The emergence of a liability for which a provision has been created, reduces the provision. Not utilizing the provision, to reduce the risk or eliminate the risk for which the provision has been created, causes the increase of operating income, financial income or extraordinary income during days for which they turned out to be unnecessary (Accounting Act, Art. 35d Sec. 2-4).

In accordance with Annex 1 to the Polish Accounting Act provisions in the balance sheet are included in the following three groups (Gabrusewicz, Remlein 2007, 107):

1) provisions for deferred income tax,

2) provision for retirement and similar benefits, divided into long-term and short-term,

3) other provisions, divided into long-term and short-term provisions.

Provision for deferred income tax is established in connection with positive temporary differences between the carrying values of assets and liabilities and their tax values, which will in the future increase the tax base. This provision is associated with a kind of deferring of income tax payments for subsequent periods, when the carrying value of an asset or liability is recovered or settled. In a situation when the carrying value is recovered, the positive temporary difference will reverse and there will be taxable income and, consequently, a fall in assets which embody economic benefits (Olchowicz, Tłaczała 2009, 218, 220; Gabrusewicz, Remlein 2007, 107-108).

It should be noted that, when the annual financial statement of an entity is not subject to an audit, the entity may waive determining of assets and provisions due to deferred income tax (Accounting Act, Art. 37 Sec. 10).

Provisions for retirement and similar benefits, cover future liabilities of an entity in relation to the employees, resulting from collective bargaining agreements, employment contracts, remuneration regulations, etc. These include, in particular (Foremna-Pilarska, Radawiecka 2007, 327-328; Gabrusewicz, Remlein 2007, 108):

- retirement and disability benefits,

- jubilee awards,

- pay for unused annual holiday,

- awards and bonuses, 
- provisions for sabbaticals, etc.

The amount of provisions for retirement and similar obligations requires consideration of many factors such as number of employees, the structure of employees by age, the amount of the average wage, the rate of inflation.

It is worth noting that according to the Polish Accounting Act [Art. 39 Sec. 2 point 2, Sec. 2a] provisions for pensions and similar obligations are recognized during the year as accrued expenses, but only at the balance sheet date are accounted for as provisions for liabilities. This specific solution adopted only in the Polish Accounting Act, which it is not reflected in the IAS, in which both during the year and at the balance sheet date, the provisions are treated as typical provisions for liabilities (Stępień 2011, 373).

Other provisions specified in the balance sheet include, in particular (Sprawozdanie finansowe 2009, 8-36):

- provisions for losses on business transactions in progress,

- provision for future liabilities resulting from restructuring,

- a provision for the expected costs and losses caused by dropping or loss of ability to continue business operations,

- passive accruals arising from obligation, related to current operations, future benefits for unknown persons, whose amount can be reliably estimated, although the date of liability is not yet known, including guarantees and warranty for sold, long-term use products,

- other future liabilities.

It should be noted that these are just examples of reasons for which provisions are created. The Polish Accounting Act in Art. 35d indicates that provisions are created "on certain or highly probable future liabilities that can be reliably estimated, especially (...)". This means that the catalogue of these provisions is open.

The basis for determining the value of the provision is a reliable estimate of the effect of an event to which it relates. The Accounting Act does not limit the obligation to create provisions to the balance sheet date, and for this reason entities are required to create provisions also during the fiscal year, if an event occurs, whose effect should be included in the financial statement (Walińska 2010, 307).

In accordance with Art. Sec. 28. 1 point 9 of the Accounting Act, no rarer than at the balance sheet date, provisions are measured at reasonable, reliable estimated value. A feature of the provision is uncertainty both in terms of maturity of liabilities, as well as its size. Therefore, the estimation of provisions 
should be conducted using the knowledge and professional judgment of the management of an entity, based on past experience, using the expertise of independent experts in a given field, and statistical estimation methods of provisions. The amount, for which a provision is created, should be the amount that an entity would pay to settle the obligation at the balance sheet date based on the most appropriate estimate (Sprawozdanie finansowe 2009, 8-52).

\section{PREMISES TO CREATE WRITE-DOWNS OF ASSETS}

The impairment loss of an asset shall be understood as the amount of reduction for the balance sheet date, or any other day, of the book value of this component, resulting from the register during a reporting period. As a rule, the effect of the impairment loss is a cost, and therefore a write down of assets value. As a result, impairment losses are a balance sheet category - reducing the value of assets, but also are a cost of the revaluation of assets (Kutera, Hołda, Surdykowska 2006, 91-92).

In accordance with the accounting practices, impairment losses may result from two, main reasons, namely (Kutera, Hołda, Surdykowska 2006, 91-92):

- loss of asset value,

- valuation of assets according to specific parameters ${ }^{1}$.

The loss of assets value, which requires a relevant impairment loss to be carried out, is a reduction of the carrying value of assets, a reduction which differs from the normal, expected consumption, expressed in amortization write offs (Rachunkowość finansowa 2011, 138). This applies to extraordinary circumstances that indicate a loss in the potential of assets to generate economic benefits. The use of impairment loss write offs is very important for the preservation of equity and continuation of the enterprise.

The Polish Accounting Act in Art. Paragraph 28.7, introduces a definition of the so-called permanent loss of value, according to which "permanent loss of value occurs when there is a high probability that the asset being controlled will not generate in the future, a significant or substantial part of the expected economic benefits". The result of the existence of permanent loss of value, is a revaluation write off to level the asset value resulting from the accounting records to the net sales price, and in the absence thereof - to estimated fair value, set using a different method.

1 Pertains to valuation of short-term investments, especially financial assets. 
Polish Accounting Act also indicates the circumstances in favor of making a write off for permanent loss of asset value. Such impairment allowance is made for (Stępień 2013b, 691):

- changes in production technology,

- liquidation,

- withdrawal from use,

- other causes of permanent loss of asset value.

The International Accounting Standards (IAS) point at the following premises of loss of asset value:

- loss of the market value of a given asset recorded during a period, is much greater than the loss which could be expected as a result of the passage of time or normal use,

- during a given period occurred or will occur in the near future, significant and detrimental to the entity changes in technology, market, economy, legal system in which the entity operates,

- evidence is available of obsolescence of an asset or its physical damage,

- during a given period or in the near future there will be significant and detrimental to the entity changes in the scope or manner in which an asset is or will be used (plans to discontinue or restructure the operation to which the asset belongs),

- evidence is available from internal reporting that indicates that the economic performance of an asset is or will be worse than expected.

It should be noted that the loss of value in the Polish Accounting Act is accompanied by the term permanent, which is not found in international regulations. This can be interpreted in two ways, in relation (Karmańska 2003, 14):

1) fixed assets - where the phenomenon is permanent - that is, relates to a longer time period,

2) current assets - due to a short time period is non-reversible.

The scope of permanent loss of asset value, in accordance with the Polish Accounting Act, includes (Karmańska 2003, 12; Stępień 2013b, 692):

- Tangible fixed assets in use,

- Tangible fixed assets under construction,

- Shares from other entities and other investment regard as fixed assets,

- Short-term investments,

- Inventory,

- Receivables and granted loans. 
It follows that, the scope of the allowances for impairment applies to many types of assets. Entities engaged in asset write-downs are required to apply the procedures set out in specific legislation - the National Accounting Standard No. 4 (NAS 4) "Loss of asset value". NAS 4 obliges companies through the process of revaluation to (Ewolucja prawnych... 2009, 56; NAS 4 Par. 2.12):

- identify the function that each component / group / of assets has in the enterprise and on this basis classify them into operational or investment,

- set the carrying amount for each asset.

It should be noted, however, that the write-downs for impairment of assets, the valuation of which has been updated on the basis of separate regulations, reduce capital revaluation provision differences due to revaluation (and therefore are recorded in the balance sheet and do not affect the financial result).

\section{THE USE OF PROVISIONS AND WRITE-DOWNS}

\section{OF ASSETS TO MANIPULATE FINANCIAL RESULTS OF ENTERPRISES}

Given the intention to manipulate financial results, there are two ways to manipulate financial results. The first is aimed at demonstrating a positive image of the company's financial situation and positive financial results. Second, in turn, is related to the tendency to present the result worse than it is, and in extreme cases even a negative image of the company and the associated negative financial results. It is worth noting that, in business practice, however, a more common trend is the tendency to present a better than in fact, image of a company (Wąsowski 2005, 9-10).

Managers manipulating financial results are driven to do so for various reasons. Often, these reasons serve the interests of the company managed by them, but often - the self-interest of managers. With the intention to improve the image of the company managers, for example, hope to (Hońko 2007, 140):

- to be paid commission on profits,

- increase the share price on the stock exchange for the purpose of resale,

- apply for external sources of financing (loans, credits),

- acquisition of equity from capital market (the issuance of new shares),

- acquire new business contacts.

On the other hand, by presenting a worse than the true (negative) image of the company, management expects to, for example (Hońko 2007, 140): 
- reduce dividend payments,

- reduction of employee claims, some of which salaries may depend on the earned profit,

- underestimate the value of the company prior to its acquisition,

- strive to run a recovery program or initiate insolvency proceedings,

- demonstrate a significant improvement in the company in subsequent reporting periods.

Depending on the direction of manipulating the financial result, there are various ways to use provisions and write-downs. In order to improve (increase) the financial result using the provisions, enterprises usually use the following manipulation techniques:

- avoiding creating provisions, despite apparent premises,

- creation of provisions, but decreasing their value in relation to the actual needs (underestimation of provisions),

- dissolution of provisions, although the circumstances for which they were created have not ceased,

- dissolution of provisions, but not recording them directly in costs, but as capital from revaluation.

In contrast, with the intention of reducing the financial result through the use of provisions, the manipulation techniques used are:

- creation of provisions, despite the lack of premises for doing so (modifying events to create fictional provisions),

- overstating the value of provisions in relation to the actual needs (over-valuation of provisions),

- not dissolving already created provisions, despite the cessation of circumstances for which they were created.

In the case of write-downs of assets, the most commonly used manipulation techniques are:

- avoiding creating provisions, despite apparent premises,

- manipulating the amount or period in which a write-down was made,

- manipulating the period or the amount of "reversal" (dissolution) of a write-down.

Individual manipulation techniques associated with the creation of provisions or write-downs of assets are accompanied by various economic circumstances. Techniques to increase the financial result are typically used in situations when the company intends to apply for new loans or credits, or seeks to issue new shares. Enterprises that show gains have easier access to new 
sources of financing. Therefore, some managers take actions aimed at showing a profit when in fact there is a loss in the company or showing profits higher than their actual state. In addition, if a company managed by them, from one period to another generates profits and share prices at the stock market rise, they are better assessed both by the owners of the company and all its surroundings, which translates into the amount of remuneration paid to them (management contracts).

Techniques to reduce the company's financial result are typically used in situations where a company has incurred a loss in a given period. Increasing the loss by using provisions or write-downs of assets in a given period, is intended to demonstrate a significant improvement in the company in subsequent reporting periods. This is done through a timely dissolution of previously established provisions and write-downs, and so increasing the company's revenues.

Reducing the financial result by using provisions and write-downs of assets also occur in cases when, the company during a given reporting period generated a high profit, but for the next few years expects a significant decrease in profits, or even losses. In such circumstances, very often part of the profit from the current reporting period is transferred to the subsequent ones. The year in which there has been a high, true profit, the profit is artificially lowered by means of provisions or write-downs of assets, so in later years, when it is low, or there is even a loss, previously created provisions and write-downs of assets are dissolved to increase the financial result.

In practice, to manipulate financial results write-offs are often used for the permanent loss in the value of real estate, recorded as fixed assets or long-term investments, or write-downs of inventories and receivables.

In the case of write-downs for permanent loss in value of real estate, a rather important issue is the manipulation of the write-down amount. It would seem that in the case of real property, that is assets of usually high value, the amount of write-downs for permanent loss of value should not be questioned because it is determined based on a valuation performed by an appraiser. However, in practice, valuations are performed by several appraisers, and the management uses the valuation which best fits their goals as valuations of individual appraisers can vary significantly.

One of the adjustments to assets value very often not performed in the Polish economic conditions is write-downs of inventory). In the case of write-downs of inventory, an adjustment is necessary due to the loss of value of inventories and as a result of the balance sheet valuation at a price not higher than their 
net selling price. When estimating value possible to attain for the balance sheet date, the most reliable evidence available at the time of the estimates should be used and estimates should take into account price fluctuations. Thus, a writedown depends on an estimate and evaluation of future events, which gives ample opportunities of "explaining" the impairment loss or not doing it at all. In Poland, entities usually do not make inventory adjustments, which remain in the warehouse.

Frequent manipulations, in practice, relate to write-downs of receivables. In accordance with Art. Par. 28.1 point 7 of the Polish Accounting Act, receivables are measured at the balance sheet date for the amount due, maintaining precautionary principles. This method of valuation results in making the impairment loss on the probability of payment of the total amount.

Pursuant to Art. 35b of the Accounting Act, write-downs of values of receivables are performed in relation to:

1) receivables from debtors in liquidation or bankruptcy;

2) receivables from debtors in case of dismissal of the bankruptcy petition, if the debtor's assets are not sufficient to cover the costs of bankruptcy proceedings;

3) receivables challenged by debtors and payment of which the debtor is overdue, and according to the assessment of the debtor's financial assets and liabilities, repayment in the contractual amount is not probable;

4) receivables equivalent to amounts increasing the receivables in respect of which a write-down has been made;

5) receivables overdue or not overdue with a significant probability of defaults, according to the kind of business or the structure of recipients.

As follows from the conditions mentioned, one of the main determinants to qualify a receivable as default and writing it down, is the evaluation of probability of repayment and the assessment of the financial situation of the debtor. For objective reasons, clearly establishing these parameters can pose many difficulties and provide opportunities for misuse.

Extremely reprehensible example of lowering the financial result using provisions and write-downs of assets is striving to underestimate the value of the company. Such actions are intended to lead to bankruptcy or contribute to its acquisition by another operator on terms favorable to the transferee. Often in such cases, managers are tied to the receiving entity and can count on personal benefits as result of these actions. 
It is worth noting that, methods often associated with the use of provisions or write-downs of assets in order to manipulate earnings, are connected to the so-called obscured image of the company.

This action usually involves a conscious and deliberate non-disclosure in the financial statements - in the notes (accountants notes) - details of the true reasons for creating and dissolving provisions or write-downs of assets. Moreover, in many of these cases, there is also no description of the accepted methods of valuation of the estimated values, in the accounting policy of the company.

\section{FINAL REMARKS AND CONCLUSIONS}

Provisions and write-downs of assets are specific economic categories related to the valuation of corporate resources. As estimates, require - at the time of their creation and valuation - one's own judgment of an entity, which is discretionary and often raises doubts as to the correctness of their valuation and the reasonableness of their creation.

The problem becomes especially visible when the provisions and writedowns of assets are used by company management to create financial results, both as instruments of increasing and decreasing the result, depending on the needs of managers.

It is worth noting, that presented a problem to manipulate of financial results of enterprises using estimated values has not only a microeconomic dimension, but also and macroeconomic. Based on the information from the financial reports, are undertaken a variety of economic decisions, e.g. financial lending to businesses through banks, as well as decisions of investors in terms of capital investment in the financial markets. Thus, the problem has a significant impact on the security of economic turnover.

It should be noted, that the problem of manipulating of estimated values has a global dimension. As in Poland, also in other countries, no exist effective solutions to eliminate this phenomenon. Accounting is facing a kind of challenge, aimed at eliminating or at least substantially reducing this practice. It is worth considering what steps need to be taken in this regard.

A reasonable solution might be to take preventive measures, involving the development of detailed regulations and rules relating to the procedure of creating and valuation of these estimates. These preventive measures should also be associated with mandatory disclosure of detailed information regarding the 
creation of provisions and write-downs of assets, both in the financial statements, as well as the company's accounting policies.

One has to be aware, that these preventive measures will not eliminate the manipulative behavior of the management of companies. The measures can, however, contribute to a significant limitation of this behavior, which can be considered a success in the future.

It is also worth to mention the role and responsibilities of auditors in terms of the justification for creating and releasing and determining the amount of provisions and write-downs of assets in the enterprise. Both provisions and write-downs of assets are key reporting items, subject to control by an auditor.

\section{REFERENCES}

Ewolucja prawnych rozwiązań współczesnej rachunkowości (2009), Micherda B. (ed.), C. H. Beck, Warszawa.

Fil P., Michalczyk A. (2007), Problemy wyceny aktywów i pasywów według MSR/MSSF i ustawy o rachunkowości, ODDK, Gdańsk.

Foremna-Pilarska M., Radawiecka E. (2007), Rachunkowość na tle rozwiązań międzynarodowych, Difin, Warszawa.

Gabrusewicz W., Remlein M. (2007), Sprawozdanie finansowe przedsiębiorstwa, PWE, Warszawa.

Gmytrasiewicz M., Karmańska A. (2006), Rachunkowość finansowa, Difin, Warszawa,

Hońko S. (2007), Zasada ostrożności a oszustwa księgowe, [in:] Sprawozdawczość i rewizja finansowa w kształtowaniu wiarygodności informacji ekonomicznej, Micherda B. (ed.), Uniwersytet Ekonomiczny w Krakowie, Kraków.

IAS 37 [in:] Międzynarodowe Standardy Sprawozdawczości Finansowej MSSF (2011), SKwP, IASB, Warszawa.

Karmańska A. (2003), Utrata wartości aktywów według prawa bilansowego, KIBR, Warszawa.

Kutera M., Hołda A., Surdykowska S.T. (2006), Oszustwa księgowe - teoria i praktyka, Difin, Warszawa.

Micherda B. (2006), Problemy wiarygodności sprawozdania finansowego, Difin, Warszawa.

National Accounting Standard No. 4 (NAS 4) "Loss of asset value", http://www.mf.gov. pl (accessed: 20.03.2015).

Olchowicz I., Tłaczała A. (2009), Sprawozdawczość finansowa według krajowych i międzynarodowych standardów, Difin, Warszawa.

Rachunkowość finansowa z uwzględnieniem MSSF (2011), Pfaff J., Messner Z. (eds.), PWN, Warszawa.

Sprawozdanie finansowe według polskich i międzynarodowych standardów rachunkowości (2009), Świderska G. K., Więcław W. (eds.), Difin, Warszawa. 
Stępień K. (2011), Rezerwy jako instrument manipulowania wynikiem finansowym przedsiębiorstwa, Prace i Materiały Wydziału Zarządzania Uniwersytetu Gdańskiego, Sopot, nr 1/1.

Stępień K. (2013a), Stosowanie wielkości szacunkowych a wiarygodność wyceny w rachunkowości, [in:] Współczesne uwarunkowania kwantyfikacji w rachunkowości, Micherda B. (ed.), Difin, Warszawa.

Stępień K. (2013b). Odpisy aktualizujące wartość aktywów jako instrument manipulowania wynikiem finansowym przedsiębiorstwa. Zeszyty Naukowe Uniwersytetu Szczecińskiego nr 766, Finanse, Rynki Finansowe, Ubezpieczenia nr 62, Szczecin.

Ustawa z dnia 29 września 1994 r. o rachunkowości, (Acounting Act), (Dz. U. z 2009 r., Nr 152, poz. 1223 ze zm.).

Walińska E. (2010), Rozliczenia międzyokresowe i rezerwy, [in:] Rachunkowość finansowa - ujęcie sprawozdawcze i ewidencyjne, ed. E. Walińska, Oficyna Wolters Kluwer business, Warszawa.

Wąsowski W. (2005), Kreatywna rachunkowość - fałszowanie sprawozdań finansowych, Difin, Warszawa.

Wojas M. (2008). Częstotliwość tworzenia rezerw i ich wpływ na kształtowanie sytuacji finansowej polskich przedsiębiorstw. Zeszyty Naukowe Uniwersytetu Ekonomicznego w Krakowie Nr 768. 